and capital development, was estimated at about 2 per cent in 1955. Between one-third and one-half of this work was done in Government laboratories and nationalized industries, and much of the remainder was financed by the Government. There were no estimates for 1939 and 1950. The Advisory Council on Scientific Policy is considering the whole question of the extent to which Britain's resources are devoted to research, and the results of this investigation will be issued in due course.

\section{Emigration of British Professional Men}

ThE Under-Secretary of State for Commonwealth Affairs, replying to a question in the House of Commons on February 14, gave the numbers of Commonwealth citizens with professional qualifications who have left the United Kingdom direct by sea to reside for more than one year in countries outside Europe during the years 1953-55 and the first half of 1956 as follows : $1953,7,730 ; 1954,6,906$; $1955,6,228 ; 1956,2,804$. The proportions to total emigrants of working age were $7 \cdot 6$ per cent, $7 \cdot 3$ per cent, $7 \cdot 6$ per cent, and $5 \cdot 6$ per cent, respectively. Of the total for the first six months of 1956,808 were teachers, 116 had legal qualifications, 38 medical, 710 professional engineering and 790 other professional qualifications. 'The corresponding figures for the three previous years are: $1953(2,882,236$, $984,1,802$ and 1,826$) ; 1954(2,684,190,972,1,344$ and 1,716$) ; 1955(2,552,158,876,1,104$ and 1,540$)$.

\section{The Siting of Power Stations}

REPLYING to questions in the House of Lords on January 29 as to the authority deciding the location of nuclear power stations and the grounds on which such decisions are based, Lord Mills said that the Central Electricity Authority was responsible for selecting the sites in England and Wales for electric power stations. The most important criteria, which are set forth in the Authority's Annual Report for the year ended March 31, 1956, are large and readily available supplies of water for cooling purposes and ground formation capable of bearing the extremely heavy reactors. Before proceeding with the construction of nuclear power stations on the selected sites the consent of the Minister of Power was required and also planning permission under Section 35 of the Town and Country Planning Act, 1947. Pressed by Lord Lawson and Lord Lucas of Chilworth as to public disquiet, Lord Mills agreed that the Minister should make all proper inquiries to enable him to make a right and wise decision. He agreed that there were many criteria to be considered and that he would be lacking in his duty if he did not take into account any disquiet there might be on this subject. There were many more nuclear power stations to be built and he was impressed with the importance of preserving the amenities of the countryside, as far as possible, in developing those plans. $\mathrm{He}$ also promised to bear in mind Lord Alexander of Hillsborough's request for improvemont in the judicial character of any inquiries.

\section{Designation of Quantock Hills}

'THE first part of England to be established as "an area of outstanding natural beauty" is the Quantock Hills, Somerset. Like the Gower Peninsula in Wales, it is the subject of an order made by the National Parks Commission under the National Parks and Access to the Countryside Act, 1949, and confirmed by the Minister of Housing and Isocal Government.
The effect of the order is to place upon the local planning authority, Somerset County Council, the special responsibility of preserving and enhancing the natural beauty of the landscape. The Quantock Hills stretch from Bridgwater Bay, in the Bristol Channel, south-eastwards towards Taunton. There are thirtyeight square miles of sandstone hills, rising to a height of 1,261 ft. above Crowcombe, with smooth downs, wooded combes, picturesque villages, fine manor houses and farmlands, rich in folk-lore and literary associations. Government grants at the rate of 75 per cent are available towards the cost of treating derelict land, tree planting and preservation, and removing disfigurements. Grants are also available towards expenditure incurred in making agreements with landowners for public access to open country, and in appointing wardens. Designation does not of itself provide any additional right of access to private land.

\section{Scientific World}

ThE first issue of the Scientific World, published by the World Federation of Scientific Workers, includes contributions from the United States, the Soviet Union, England, Brazil, Czechoslovakia and India on such varied topics as automation, the training of Soviet research workers, the Bessemer centenary, the present position of research and scientific workers in Brazil, India's fuel prospects and contacts between Soviet and American microbiologists. A communication from Czechoslovakia on common problems of scientists elaborates more fully what the editorial board hopes to achieve through the new periodical in presenting a balanced reflexion of the thought of scientists throughout the world on the social relations of science, the conditions best promoting the healthy growth of science and the application of its results for human welfare, with the aim of expanding co-operation in the constructive application of science. In particular, it is hoped to promote the international expression of the views of individual scientists and to assist in disseminating knowledge of the progress of the special agencies of the United Nations.

\section{The Institute of Biology}

THE Institute of Biology has elected Prof. W. H. Pearsall as its president for 1957. Prof. Pearsall played a leading part in the foundation of the Institute and has taken an active interest in promoting its growth to the present membership of 1,300 full members, 90 associate members and 280 student members. Mr. H. J. Bunker has succeeded Dr. G. E. Fogg as the Institute's honorary secretary and brings to the office the experience of seven years service on the Council of the Institute. The Journal of the Institute of Biology, which contains articles of general biological interest, comment on those matters which affect the professional interests of biologists, book reviews and news of matters biological, is now available to the public at a price of $10 s$. $6 d$. per volume of four quarterly parts. Jointly with the Biological Council, the Institute of Biology has published a "Diary of Meetings of Biological Societies, 1957", copies of which are now available. During 1957, in addition to meetings of branches, the Institute is arranging a discussion on "The Nutrition of Parasites", a meeting on the professional problems met by bio.' logists working in the Colonies and a two-day symposium on "The Biological Productivity of Britain". Further information can be obtained from the General 